\title{
100 Years since the birth of Ladislau Steiner. Creativity of Neurosurgery
}

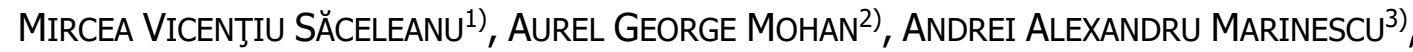 \\ AleXANDRu VLAD CiUREA ${ }^{3,4)}$ \\ 1) Department of Neurosurgery, Victor Papilian Faculty of Medicine, Lucian Blaga University, Sibiu, Romania; \\ Department of Neurosurgery, Emergency County Hospital, Sibiu, Romania \\ 2) Department of Neurosurgery, Faculty of Medicine and Pharmacy, University of Oradea, Romania; \\ Department of Neurosurgery, Bihor Emergency County Hospital, Oradea, Romania \\ 3) Carol Davila University of Medicine and Pharmacy, Bucharest, Romania \\ 4) Department of Neurosurgery, Sanador Clinical Hospital, Bucharest, Romania
}

\begin{abstract}
Ladislau Steiner (1920-2013) was a Romanian neurosurgeon, born in the historic and picturesque region of Făgăraş. He was educated by some of the best doctors and professors in Romania, during the communist regime. After his escape through the communist regime, in 1961, at 41 years old, he started his neurosurgical and radiosurgical career at Karolinska Institute, in Stockholm, under the renown Herbert Olivecrona and Lars Leksell. He worked here for 25 years, until he retired in 1987 as head of $1^{\text {st }}$ and $2^{\text {nd }}$ Departments of Neurosurgery in the institute's affiliated clinic Sophiahemmet Hospital. He is most known in Sweden as the first to introduce microsurgical techniques in neurosurgery, but internationally he is known as "the unofficial emissary of Gamma Knife Surgery". After his retirement, he continued his practice at University of Virginia, USA, for another 23 years and another two years at International Neurosciences Institute, Hannover, Germany, being a Professor of Neurosurgery and Radiology of Gamma Knife Surgery. Thanks to his efforts, Romanian neurosurgery had an accelerated progress after the fall of communism, in 1989. Also, thanks to him, Romania was the first Southeast European country with a Gamma Knife unit. For his efforts, he was appointed Honorary President of the Romanian Society of Neurosurgery. We pay tribute to a great Romanian neurosurgeon who managed to touch the lives of thousands of patients and doctors from almost all countries in the world, in time when the world was divided between east and west, communism and freedom.
\end{abstract}

Keywords: neurosurgery, gamma knife surgery, history.

\section{ㅁ Early life and education}

Professor Ladislau Steiner (Figure 1) was born on August $26^{\text {th }}, 1920$ in Făgăraş, a small Transylvanian town from the foothills of the Carpathian Mountains.

This small town is an important historical landmark in Romania that still has its original medieval fortress intact (Figure 2). His childhood home was close to the famous Sâmbăta de Sus Monastery (Figure 3), erected by Romanian martyr and Prince of Wallachia, Constantin Brâncoveanu (1654-1714), as a symbol of Christian Orthodoxy in the region.

Steiner received a robust education from early childhood. Intelligent, hard-working, and perseverant, he graduated from high school top of his class. His medical education began at King Ferdinand University (Figure 4), Medical School in Cluj-Napoca, a 2000 years old city founded by the Romans.

This University was renowned at the time for its prestigious professors famous in Romania and Eastern Europe. Some of them include Albert Szent-Györgyi (1893-1986), who won the Nobel Prize in Physiology or Medicine in 1937 for isolating vitamin C, Dezső Miskolczy (1894-1978), who was a pupil of Ramón y Cajal (18521934), and Professor Iuliu Haţieganu (1885-1959), head of internal medicine, after which the University is currently named.
This environment proved fruitful for young Steiner, who managed during his student years to publish a few studies in the Annals of the Romanian Academy of Science, regarding conditional reflexes during experimental traumatic brain injuries and the modifications of cerebrospinal fluid in schizophrenia and epilepsy. During his studies here, he met his wife, Melita, who later became a pulmonologist. She became his closest colleague and lifelong companion.

Ladislau Steiner wrote his thesis on neuropsychiatry and graduated in 1950. As a resident, he went on to study neurosurgery under Professor Ştefan Iacob (1920-1975), in Cluj-Napoca, a famous Eastern European surgeon. These were the pioneering years of neurosurgery. There were still European countries which did not have a dedicated, autonomous neurosurgical clinic. For a few years, later in his residency, he trained under Professor Constantin Arseni (1912-1994), in Bucharest, the "father" of modern neurosurgery in Romania.

\section{ㅁ Escape through the Iron Curtain}

At this time, Romania was led by the communists. To travel and study abroad was a rarity. Thanks to his remarkable intellect and work ethic, he was allowed together with his wife to study abroad, but still in the Soviet Bloc, in East Berlin. Here, Steiner enriched his neurosurgical skills under Friedrich Weickmann (1913-1983).

This is an open-access article distributed under the terms of a Creative Commons Attribution-NonCommercial-ShareAlike 4.0 International Public License, which permits unrestricted use, adaptation, distribution and reproduction in any medium, non-commercially, provided the new creations are licensed under identical terms as the original work and the original work is properly cited. 
The couple stayed here for two years, and in 1961, together with their two sons, planned their escape over the Iron Curtain. The first step required false Italian passports, which they procured from friends in the Italian Embassy. The second step involved a basic knowledge of the Italian language. This was not a problem for Steiner who was multilinguistic. He mastered Romanian, Hungarian, French, German, Italian and English. The thirds step involved a quick separation of the family at Checkpoint Charlie, as to not arise suspicions. First, his wife, Melita and their two sons were sent off through the checkpoint. Shortly after, Steiner got through alone. The family was reunited, and the soldiers never knew that an entire family escaped [1].

\section{ㅁ A new life in Sweden}

In the 1960's, when neurosurgery was still in its early steps, there were only a handful of master neurosurgeons in Europe. One of them was Professor Herbert Olivecrona (1891-1980), who was respected worldwide. He was especially admired by the German neurosurgeons whose founder or neurosurgery, Wilhelm Tönnis (1898-1978), was his direct apprentice.

Having spent two years studying neurosurgery in Berlin, the fame of Professor Olivecrona (Figure 5) reached Steiner's ears and decided to go study under him in Stockholm, at the Karolinska Institute. Unfortunately, by the time he arrived there in 1962, Olivecrona was 71 years old and retired from Karolinska, but was succeeded by his pupil, Lars Leksell (1907-1986) (Figure 6).

As always, one problem is followed by another. When the young family arrived in Stockholm, only his wife was offered a salary as a general practitioner, while Steiner had to work pro bono at the Karolinska Institute due to budgetary constraints. This was a considerable hardship for a family of four, but they managed [1].

He started his studies anew and worked here for the next 25 years side by side with both his mentors, Olivecrona (who was now working at a private hospital) and Leksell. Due to his determination, intelligence and creativity, he raised through the ranks from resident to Associate Professor, docent consultant and, finally, he became the Head of the $1^{\text {st }}$ and $2^{\text {nd }}$ Departments of Neurosurgery in the Institute's affiliated clinic Sophiahemmet Hospital. This was accomplished through a Royal Decree, thanks to the efforts of his mentors, Herbert Olivecrona and Lars Leksell.

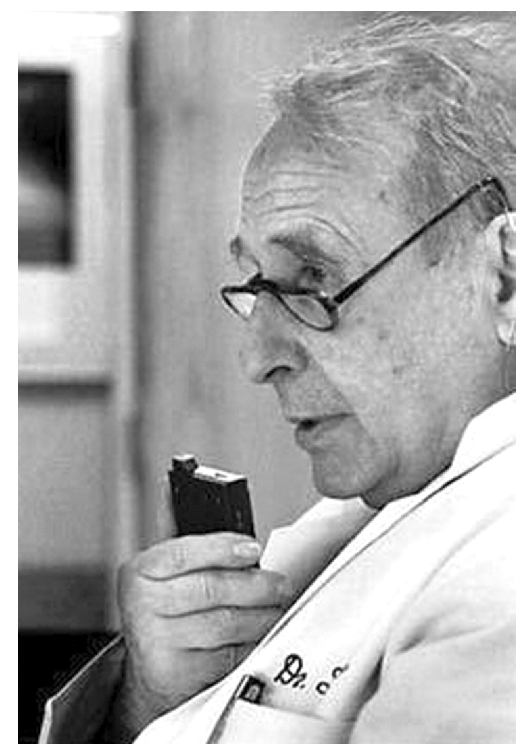

Figure 1 - Ladislau Steiner (1920-2013).

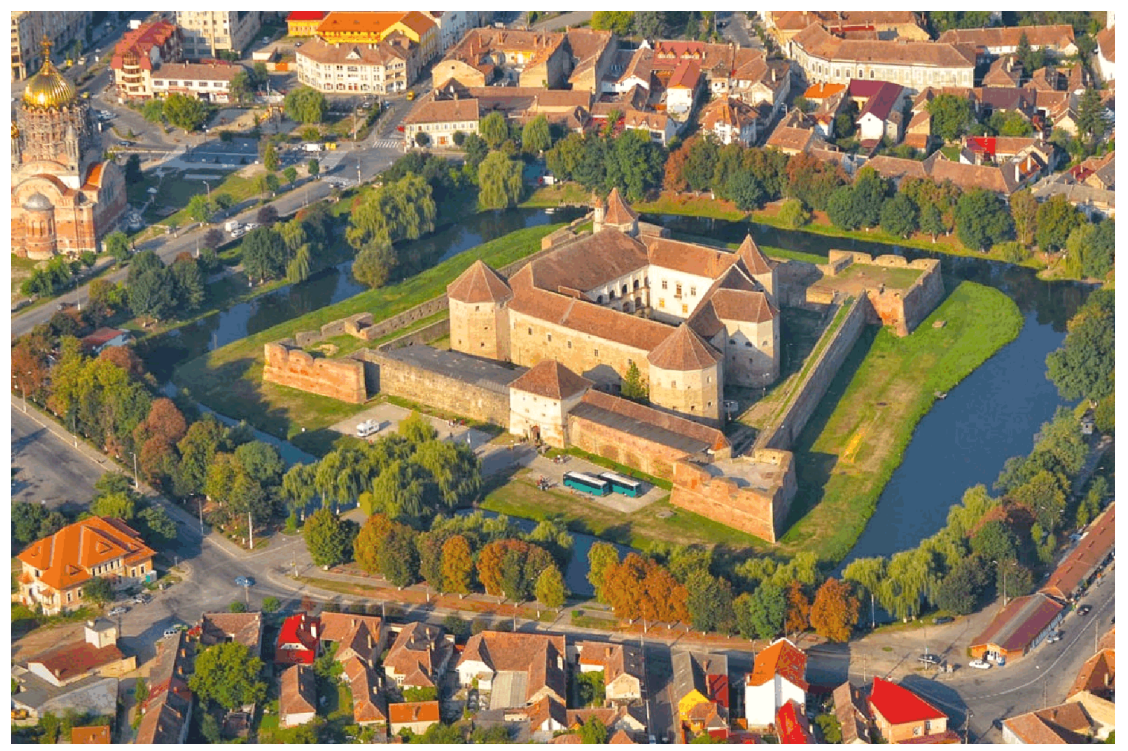

Figure 2 - Făgăraş medieval fortress, situated in the city center. Author: Valentin Iliescu (https://coltisorderomania.ro/wpcontent/uploads/2019/04/cetatea-fagaras-0-1200x800.jpg).
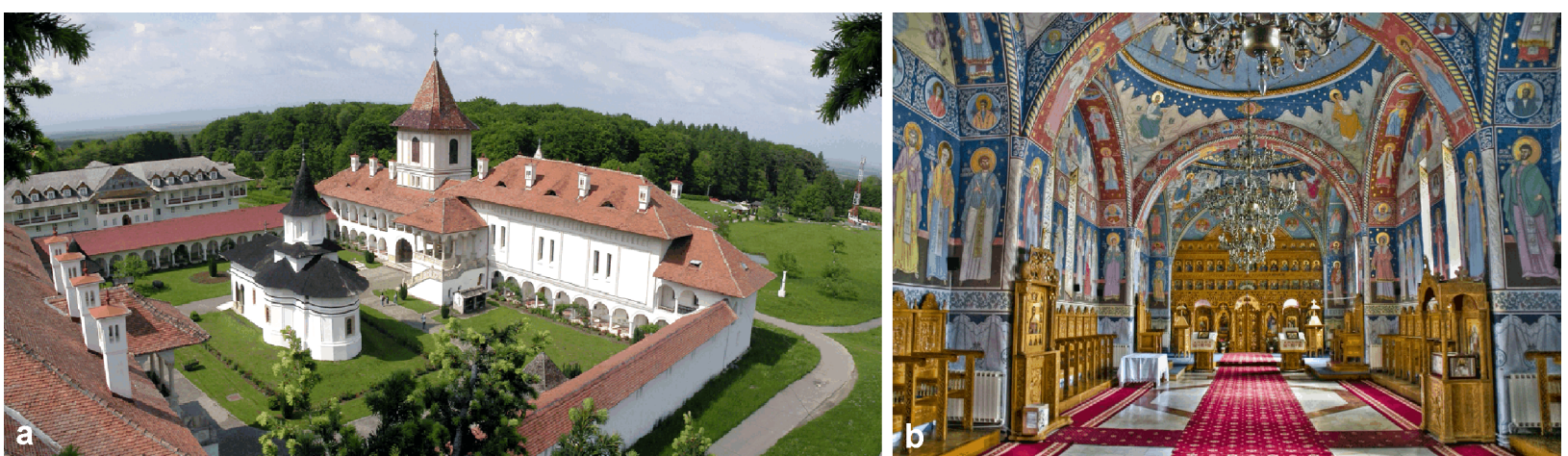

Figure 3 - Sâmbăta de Sus medieval monastery with fortifications (a) and its interior (b). Exterior photography source: http://www.sambatadesus.ro/manastirea-brancoveanu/. Interior photography author: Radu Dumitru (https://www.nw radu.ro/2012/05/culori-manastirea-sambata-sus/). 


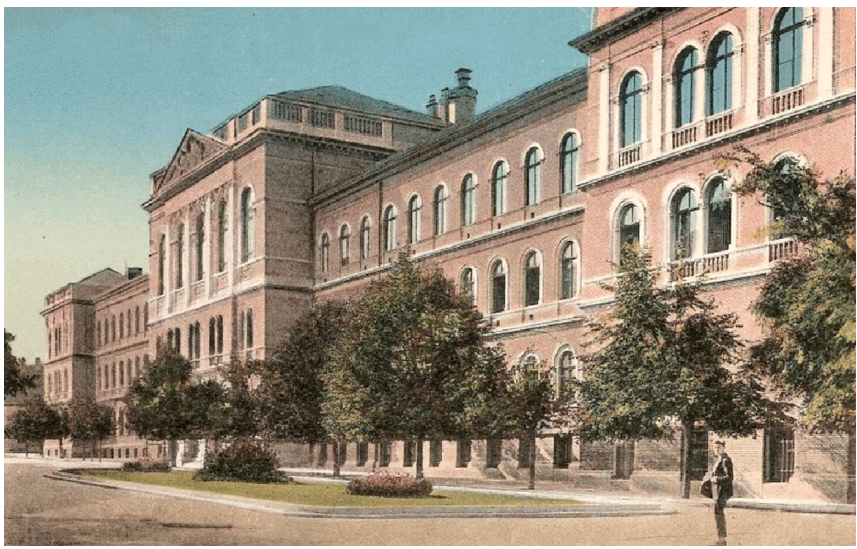

Figure 4 - King Ferdinand University, Cluj-postal card, 1926. Source: https://ziarullumina.ro/eveniment/centenaruluniversitatii-romanesti-din-cluj-150307.html.

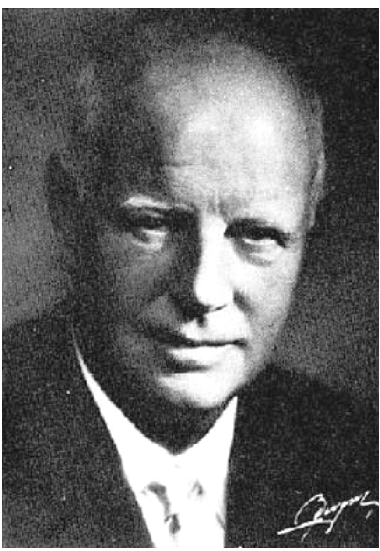

Figure 5 - Prof. Herbert Olivecrona (1891-1980), the founder of the Swedish Neurosurgery.

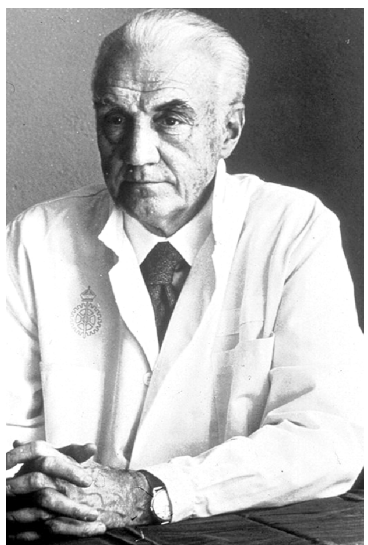

Figure 6 - Prof. Lars Leksell (1907-1986), a Swedish physician and

Professor of Neurosurgery at the Karolinska Institute in Stockholm, Sweden.

He was the inventor of Radiosurgery.
Leksell saw his potential and soon made him faculty member. At this moment, Steiner was experienced in a broad field of clinical neurosciences, but his mentor was interested in his neurosurgical skills and clinical application of innovative technologies and ideas.

Working with Olivecrona, Steiner honed his surgical skills and tried to advance the open surgery techniques. Following his mentors' path, he was the first to introduce microsurgery in Sweden. His main interest was vascular neurosurgery and benign tumors. Considering his department was responsible for the neurosurgical needs of over two million people, Steiner had the most contribution to the International Cooperative Study on the Timing of Aneurysm Surgery (1982-1984) [1-3].

In 1975, he completed his PhD Thesis: "The mechanism of death in subarachnoid hemorrhage". It was a widely appreciated experimental study that involved a frequent vascular pathology in the Scandinavian region.

\section{마 Early steps with Gamma Knife Surgery (GKS)}

While in Sweden Steiner was celebrated for advancing surgical and microsurgical techniques and technology, the international community remembers him for being the "unofficial emissary of Gamma Knife Surgery" [4].

The invention of GKS in 1968, by Lars Leksell, was a considerable milestone in the history of treatments for neurological pathologies. Naturally, he recruited the help of senior neurosurgeons of the Karolinska Institute and decided to divide the work between them. Thus, Ladislau Steiner, being the department's senior vascular surgeon, led the team working with cerebral arteriovenous malformations (AVMs) [5].

Together, they treated the first AVM patient with GKS, in 1970 [6]. As always, Steiner put the interest of the patients above all else, and only after 19 months when an angiogram confirmed the total obliteration of the AVM, he tried this new method on a second patient [7].
In 1977 , the team presented a series of 30 cases at the $6^{\text {th }}$ International Congress of Neurological Surgeons in São Paulo. The results were promising and impressed the audience. This resulted in numerous invitations from universities across Europe, North and South America and Asia for Steiner to be a Visiting Professor [1]. This was the first step towards a wide popularization of GKS: "I suppose it was the presentation in Sao Paulo that resulted in the international breakthrough for radiosurgery, and the number of patients and visiting doctors to the Karolinska multiplied. AVM patients came from all over Europe, from the Americas, and from Asia even as far away as from Japan" [4].

By 1983, 247 patients were treated using the Gamma Knife and after the complete clinical and follow-up data were available, he published his results in the Journal of Neurosurgery, in 1992 [8]. This article is still in the top 100 most-cited neurosurgical papers of all time [9].

Steiner was always very careful in choosing the treatment option for each patient. He treated each case individually and always worked in the patient's best interests, even if it meant sending the patient to a different clinic. During his practice in Charlottesville, in only two years (March 1989-March 1991), 1600 AVM's were referred to him from all around the globe. He decided to accept only 364 (22.75\%) for Radiosurgery [7].

He never refrained from scolding other neurosurgeons for their wrong usage of GKS:

"In 2010, Steiner was the Lars Leksell lecturer at the International Leksell Gamma Knife Society Meeting in Athens, Greece. Here he gave all 500 participants a scolding on ethics and morals in neurosurgery - and a memorable lesson it was!" [1].

"Leksell used to paraphrase Norman O. Brown: «A fool with a tool is still a fool». Steiner did not want to see any fools involved with Leksell's Gamma Knife" [1].

"He would not hesitate to reprimand a wrong doer and cause what he called «a small scandal» or even, if there was a need, «a big scandal»»" [4]. 
In 1987, after 25 years in the service of the Karolinska Institute, Steiner retired at the age of 67 . By this time, the GKS was no longer used only in Sweden. Two of Leksell's students managed to bring this new and exciting technology to their home countries. In 1983, Dr. Hernan Bunge installed the GKS in Buenos Aires, Argentina, and in 1985, Dr. David Forster installed it in Sheffield, UK. Also, two more units were installed in the USA: one in Pittsburg (1987) and the other in Charlottesville (1988) [5].

\section{$\varpi$ Retired, but only halfway through his career}

Even though Ladislau Steiner retired, he continued to practice in the private sector for another 26 years. As mentioned above, he now had many countries in which he could continue to teach and practice GKS. He eventually decided to move to Charlottesville, in 1988, where he became Professor of Neurosurgery and Radiology and Director of Lars Leksell Center for Gamma Knife Radiosurgery, at University of Virginia. Here, his career continued for a remarkable 23 years.

In his new headquarters at University of Virginia, Steiner organized the Lars Leksell Symposium, where discussions could be held from a multidisciplinary perspective. "At each of these occasions, he and Melita invited all participants to their home for cocktails and buffet dinners. These events were always done in style but never ostentatiously. Dinners were often to the accompaniment of classical music performed by past and current colleagues" [1].

In his new location, Steiner managed to conduct approximately 15000 GKS interventions for patients from 57 countries and six continents. In his work Radiosurgery, he left management directives for most pathologies with radiosurgical indication. During his 23-years stay at the University of Virginia, he managed to produce over 60 peer-reviewed publications, in which many colleagues from all around the world contributed [1].

\section{ㅁ A final return to Europe}

In his final years, he decided to return to Europe. In July 2010, at 90 years old, he accepts Prof. Madjid Samii's invitation to be Professor of Neurosurgery and Chief of Gamma Knife Radiosurgery at the International Neuroscience Institute in Hannover, Germany. He worked here until his death in February 2013. "The last thing he did before peacefully falling asleep was to ask us to care for a young Iranian neurosurgeon he had promised to help. His final words to us were «You must work hard»" [1].

Even though the first half of his life in communist Romania could not compare to the freedoms and incredible personal and career growth his emigration offered, Prof. Steiner never forgot his origins. As soon as the communist regime was abolished in Romania, he sought to help Romanian neurosurgery grow to the western standards. Thanks to his efforts, in 2003 a GKS unit was installed in Romania, the first country in Southeastern Europe to manage a completely autonomous GKS service.

Steiner was eager to support all scientific activities of Romanian neurosurgeons. He was the first to promote to the international community the first Black Sea Congress of Neurosurgery (1995, Mamaia) and the first DanubeCarpathian Congress of Neurosurgery (2010, Cluj-Napoca). As testament of his love for his home country, his last public appearance was in Romania, in September 2012, where his warm-hearted speech in Bucharest remained in the memory of the attendees of the International Congress of the Romanian Society of Neurosurgery.

\section{a Conclusions}

For all his efforts in supporting the Romanian neurosurgery, Professor Ladislau Steiner was named the Honorary President of the Romanian Society of Neurosurgery.

\section{Conflict of interests}

The authors declare that they have no conflict of interests.

\section{References}

[1] Leksell D, Lindquist CE. Ladislau Steiner, 1920-2013. J Neurosurg, 2013, 119(3):785-788. https://doi.org/10.3171/2013.4. JNS13564 PMID: 23870016

[2] Kassell NF, Torner JC. The International Cooperative Study on timing of aneurysm surgery. Acta Neurochir (Wien), 1982, 63(1-4):119-123. https://doi.org/10.1007/BF01728863 PMID: 7102400

[3] Kassell NF, Torner JC. The International Cooperative Study on timing of aneurysm surgery - an update. Stroke, 1984, 15(3):566-570. https://doi.org/10.1161/01.str.15.3.566 PMID: 6729890

[4] Lindquist C. Ladislau Steiner - memories of a mentor and friend. Neurosurg Rev, 2014, 37(2):171-174; discussion 174. https://doi.org/10.1007/s10143-014-0534-x PMID: 24595528

[5] Ganz JC. The history of the gamma knife. $1^{\text {st }}$ edition, Book Series "Progress in Brain Research", vol. 215, Elsevier B.V., 2014. https://www.sciencedirect.com/bookseries/progress-inbrain-research/vol/215/suppl/C

[6] Steiner L, Leksell L, Greitz T, Forster DM, Backlund EO. Stereotaxic radiosurgery for cerebral arteriovenous malformations. Report of a case. Acta Chir Scand, 1972, 138(5): 459-464. PMID: 4560250

[7] Steiner L, Lindquist C, Steiner M. Radiosurgery. Adv Tech Stand Neurosurg, 1992, 19:19-102. https://doi.org/10.1007/ 978-3-7091-6672-7_2 PMID: 1418122

[8] Steiner L, Lindquist C, Adler JR, Torner JC, Alves W, Steiner M. Clinical outcome of radiosurgery for cerebral arteriovenous malformations. J Neurosurg, 1992, 77(1):1-8. https://doi.org/ 10.3171/jns.1992.77.1.0001 PMID: 1607950

[9] Ponce FA, Lozano AM. Highly cited works in neurosurgery. Part I: the 100 top-cited papers in neurosurgical journals. J Neurosurg, 2010, 112(2):223-232. https://doi.org/10.3171/ 2009.12.JNS091599 PMID: 20078192

\section{Corresponding author}

Aurel George Mohan, Associate Professor, MD, PhD, Department of Neurosurgery, Faculty of Medicine and Pharmacy, University of Oradea, 101 December Square, 410073 Oradea, Bihor County, Romania; Department of Neurosurgery, Bihor Emergency County Hospital, 65 Gheorghe Doja Street, 410163 Oradea, Bihor County, Romania; Phone +40740-514 636, e-mail: mohanaurel@yahoo.com 